\title{
NEOCLASSICAL APPROACH TO TRADITIONAL BUSINESS INSURANCE - INTRODUCTION TO THE THEORY OF AGRICULTURAL INSURANCE
}

\author{
JACEK KULAWIK
}

\begin{abstract}
The contemporary agriculture is among the most risky economic activities. In addition to the previously known production, price and market risk, and later also the financial risk, today agricultural producers are increasingly more often confronted with institutional risk and personnel management risk and risk related to climate change. On the other hand, farmers have at their disposal numerous tools and strategies to counteract threats and mitigate their negative effects. Among these risk management instruments and strategies, traditional/ conventional insurance of crops, livestock and tangible assets is still important. In this context, the basic goal of the article is to generalise the theoretical foundations of the above-mentioned insurance, but limited to their historically oldest approach; hence on the basis of neoclassical microeconomics and classical decision theory. According to the convention existing, the essence of the theory/hypothesis of the expected utility of von Neumann-Morgenstern is first analysed. In the last part of the article, the assumptions of the expected utility theory are concretised on the example of agricultural insurance.
\end{abstract}

Keywords: risk aversion, agricultural insurance, expected utility.

JEL codes: D81, Q12, D11.

\section{Introduction}

Agricultural activity, at the very least due to its nature- and biology-related character, has always been one of the riskiest. The earliest farmers had to face primarily the production risk, i.e. fluctuations in crop yield and harvest and animal productivity due do changing weather. Later on, as the ties between the farmer 
and the social environment and the division of labour developed, the sector to an increasing extent faced price and market risks, which can jointly result in final goods sales prices lower than expected and higher prices of means of production. As a result, both the costs and the revenue fluctuate, which leads to fluctuations in agricultural income. At some point, agriculture started to be, rather indirectly, affected by volatile currency exchange rates. When farmers started to use borrowed capital, and in particular bank credit, more frequently, financial risk appeared as well. It results from the financial leverage mechanism, which can increase the return on equity, but due to the related financial burden in the form of interest on the borrowed capital, might disturb cash flows, which in extreme cases, poses a threat to the very existence of the farm. Since the Great Depression of the late 1920 s and early 1930s, when the phase of deeper state intervention in agriculture started, another risk emerged - the so-called institutional risk. This short term covers changes to the law, regulations and agricultural policy, which can radically aggravate conditions for agricultural activity, and are difficult to predict because they result from political mechanisms, where interest groups, unclear rules of decision making, rent seeking and political corruption come into play (Hoag (ed.), 2010; Hardaker, Gudbrand, Anderson and Huirne, 2015). The above list of risks can be extended even further. For instance, Robison and Barry name 10 types of risk, 20 risk management instruments, 3 types of markets (competitive, monopolistic, and regulated), 3 areas of activity (production, sales, financing), and 6 different final and intermediate goods in the generalised model of a commercial firm (Robison and Barry, 1987). In total, there are as many as 10,800 decision models under risk conditions that can be constructed. In practice, of course, such a set of combinations definitely has to be limited by adjusting it to an agricultural producer's preferences. There are appropriate analytical, modelling and simulation tools for that purpose, and computer applications that allow their users to create efficient and highly individualised risk management strategies.

Particularly important risk management tools are insurance policies on crops, livestock and other assets. This article discusses only the traditional insurance, also referred to as conventional insurance. These are products aimed at transferring the economic risk outside the farm, where, having paid the premium, the farmer expects compensation when the insured event named in the contact and thus a verifiable loss, occurs (Miranda and Farrin, 2012). These products may be highly customised, and therefore adjusted to the risk profile of the farm, but moral hazard and negative selection, which result from the asymmetric information, and the systematic risk, i.e. the difficulty in dispersing the risk when it affects a large number of farms. As a consequence, such insurance might generate high transaction cost, which contribute to the difficulties in the development of efficient private markets. Despite these disadvantages, in recent years, there has been a clear upward trend in extending conventional insurance programmes towards package solutions, i.e. solutions providing protection against many risks, stabilising agricultural revenue and income, with large subsidies (OECD 2017a; OECD, 2017b; Goodwin and Smith, 2014). It suffices to say that in Poland, agricultural insurance subsidies 
are supposed to grow 4.5 times in 2017 compared to 2016. Therefore, there is an urgent need to provide sound theoretical foundation for expansion of conventional agricultural insurance to improve them from an actuarial side, and thus improve the efficiency of public spending. A good point of entry is the expected utility theory/ hypothesis presented in a complete axiomatic approach by von Neumann and Morgenstern. It is in turn grounded in the microeconomic theory of a consumer making decisions under risk and uncertainty. Therefore, the main goal of the article is to provide a synthesis of the theoretical achievements related to the expected utility with the acceptance of the central position of risk aversion in the entire von Neumnann-Morgenstern concept. The final section presents one of the possible realisations of the said hypothesis in the area of agricultural insurance.

This article is based primarily on the English language works but occasionally cites German publications. The references do not include Polish authors except the book by Czarny (2006). The reason is simple: the analysis of the Polish literature on the theoretical basis for economic and agricultural insurance has led to the conclusion that it does not refer to the expected utility hypothesis. It is dominated by a simple description, classifications, statistics, and legal regulations. In this sense, the article at least partially fills the existing gap.

\section{Expected utility theory/hypothesis}

The above theory, referred to in the English language literature with the EU or EUT acronym (expected utility theory), speaks of decision making under risk and uncertainty, where people are not always oriented towards maximisation of the monetary value of the expected gains in games of chance or from investment. It was inspired by the so-called St. Petersburg paradox, which was described by N. Bernoulli in 1713, but named so by his cousin Daniel, who explained it mathematically in 1738. It is a game of chance, which can result in infinite expected value, but in practice the players perceive it as less valuable. In 1728, Cramer, a Swiss mathematician wrote in his letter to N. Bernoulli that "the mathematicians estimate money in proportion to its quantity, and men of good sense in proportion to the usage that they may make of it" (Zweifel and Eisen, 2012). Cramer also observed that money can be characterised by the diminishing marginal utility for the winning players, which he proved using the square root utility function. D. Bernoulli, on the other hand, took account of all their wealth, and used the logarithmic utility function to explain the above paradox. In consequence, it turned out that the same prize had a different value, utility, for a wealthy person and for a poor one. It was later observed, however, than D. Bernoulli's reasoning was not too rigorous. The crux in the matter lies in the fact that the logarithmic function implies unlimited utility, and thus allows such a manipulation of the game that the expected utility can be infinite. As a result, we return to the beginning. This observation was made for the first time in 1934 by Menger. This led to introduction of restrictions on the utility function values. It is clearly visible in the von Neumann-Morgenstern approach, i.e. the theoretical basis for risk management, including purchase of an insurance policy. For the sake of orderliness, let us add here that the St. Petersburg paradox is 
also explained using finite lotteries. In essence, this is based on the fact that a very high expected value might results from the occurrence of very rare high prizes, which even exceed what the organiser is able to pay. In this sense, the expected value of the prize automatically becomes a finite sum where the organiser sets an upper limit to the payment.

Von Neumann and Morgenstern presented the basics of their theory in a 1944 book titled Theory of Games and Economic Behavior. However, its complete form was shown as late as its second and third edition (of 1953). In general, it is an axiomatic theory. Below is its general outline based on the work by Dhami (2016).

Given is a constant finite set of real numbers $X=\left\{x_{1}, x_{2} \ldots, x_{n}\right\}$ such that $x_{1} \leq x_{2} \leq \ldots \leq x_{n}$. The above set might be treated as possible level of wealth/assets of a certain agent. Let $L$ be the following simple game, also referred to as a wager or a lottery:

$$
L=\left(x_{1}, p_{1} ; x_{2}, p_{2} ; \ldots ; x_{n}, p_{n}\right)
$$

where: $p_{1}, p_{2}, \ldots p_{n}$ are probabilities of game outcomes $x_{1}, x_{2} \ldots, x_{n}$, where $p_{i} \in[0,1]$ and $\sum_{i=1}^{n} p_{i}=1$. The expression $\left(x_{i}, 1\right)$ is interpreted as a sure outcome. In practice, simple games can be combined. Such compound lotteries, e.g. $L_{1}$ and $L_{2}$ are noted as $\left(L_{1}, p ; L_{2}, 1-p\right)$, where $p \in(0,1)$. A special case is the game in the form of $(L, p$; $0,1-p)$, which is also denoted $(L, p)$. If probability can be determined objectively, i.e. through measurement, it is a case of risk. If, however, probability is estimated subjectively, it is a case of uncertainty. Below, we deal only with game under risk. Dhami denotes it $\mathcal{L}^{\prime} \subset \mathcal{L}$.

In the von Neumann-Morgensterm theory (VNM), there are five axioms, which essentially reflect the relationships between the agent's preferences. Hence the specific notation, which is derived from the convention used in the consumer theory, in the absence of risk and uncertainty (Jehle and Reny, 2011). This is followed by the following notation for relationships between the lotteries:

a) $\succeq$ "at least as good as"; for lottery $L_{1}, L_{2} \in \mathcal{L}$ we have $L_{2} \succeq L_{1}$, i.e. "lottery $L_{2}$ is at least as good (profitable) as lottery $L_{1}$. In other words, lottery $L_{2}$ is "weekly preferred" to lottery $L_{1}$. Notations $L_{2} \succeq L_{1}$ and $L_{1} \preceq L_{2}$ are equivalent.

b) $\succ$ "preferred to". Strict preferences.

c) $\succ$ "worse than". Notation $L_{2} \succ L_{1}$ is equivalent to $L_{1} \prec L_{2}$. Strict preferences.

d) "indifference/neutral relation".

Axiom 1: Order. It consists of two conditions:

a. completeness: for all lotteries $L_{1}, L_{2}$ we have: either $L_{2} \succeq L_{1}$ or $L_{1} \preceq L_{2}$;

b. transitivity: for all lotteries and $L_{1}, L_{2}, L_{3}, L_{3} \succeq L_{2}$ and $L_{2} \succeq L_{1} \Rightarrow L_{3} \geq L_{1}$ The two following binary relations between lotteries may also be defined in the $\succeq$ convention as: 


$$
\left\{\begin{array}{l}
\text { indifference: } L_{1} \sim L_{2} \Leftrightarrow L_{2} \succeq L_{1} \text { and } L_{1} \succeq L_{2} \\
\text { strict preference: } L_{2} \succ L_{1} \Leftrightarrow \text { is not equivalent to } L_{1} \succeq L_{2} .
\end{array}\right.
$$

Axiom 2: The best and the worst:

$$
x_{n} \succ x_{1}\left(t j .\left(x_{n}, 1\right) \succ\left(x_{1}, 1\right)\right)
$$

Axiom 3: Continuity: for each lottery $L$, there is probability $p \in[0,1]$ such that $L \sim\left(x_{1}, 1-p ; x_{n}, p\right)$.

Axiom 4: Independence: for all lotteries $L_{1}, L_{2}, L$ and for all $p \in[0,1]$, $L_{2} \succeq L_{1} \Leftrightarrow\left(L_{2}, p ; 1-p\right) \succeq\left(L_{1}, p ; L, 1-p\right)$.

Axiom 5: Reduction or combining/compounding of lotteries: let $p_{1}, p_{2}, p \in[0,1]$, and let $L_{1} \sim\left(x_{1}, 1-p_{1} ; x_{j}, p_{1}\right)$ and $L_{2} \sim\left(x_{1}, 1-p_{2} ; x_{j}, p_{2}\right)$. Then:

$$
\begin{gathered}
\left(L_{1}, p ; L_{2}, 1-p\right) \sim\left(\left(x_{1}, 1-p_{1} ; x_{j}, p_{1}\right), p ;\left(x_{1}, 1-p_{2} ; x_{j}, p_{2}\right), 1-p\right) \\
\sim\left(x_{1},\left(1-p_{1}\right) p+\left(1-p_{2}\right)(1-p) ; x_{j}, p p_{1}+(1-p) p_{2}\right)
\end{gathered}
$$

The independence axiom is crucial in the VNM theory. It requires that if $L_{2}$ lottery is preferred to $L_{1}$ addition of another lottery should not change the preference. This axiom is the subject of the strongest criticism by economists and behavioural finance specialists, who question it very often and argue that it usually diverges from the actual conditions of decision making (Ackert amd Deaves, 2012; Döring, 2015; Kunreuther, Pauly and McMorrow, 2013; Rejda and McNamara, 2017).

All of the above five axioms jointly form the rationality axiom. It follows follows that if a binary rel $\_\succeq$ on defined on set $\mathcal{L}$ is compatible with it, it will be rationally ordered. If the above binary relation occurs and if there is a utility function $U: L \rightarrow \mathrm{R}$, such that for all $L_{1}, L_{2} \in \mathcal{L}, L_{2} \geq L_{1}$, then the condition that $U\left(L_{2}\right) \geq U\left(L_{1}\right)$ has to be simultaneously met. Then $U$ represents $\succeq$, and this relation is triggered by $U$. Now, we can write the VNM expected utility function as:

$$
U(L)=\sum_{i=1}^{n} p_{i} u\left(x_{i}\right)
$$

where:

$x_{i} \quad$ - possible lottery outcome from set $\mathcal{L}$,

$u\left(x_{i}\right)$ - a real number assigned to outcome $x_{i}$.

It follows from the above general notation of the VNM function that the agent should prefer growth in the expected utility, so it will be an agent maximising the expected utility. The function itself shows linearity in relation to the probabilities, invariability in relation to the positive affine transformations and depends on the terminal wealth in each state of nature. The last of these, in turn, implies the necessity to divide the domain into the zone of lottery gain and the zone of lottery loss. 
In the end, the outcome strongly depends on the choice of the analytical form of the above function. The ones that are usually used are the logarithmic, square, exponential and power functions. The ordering of lottery prizes is then very diverse, hence the problems with choosing the adequate decision rule (Moss, 2010; Robison and Barry, 1987).

In response to the formal criticism of the EU and the impractical nature of the key axioms of the VNM function, the subjective expected utility (SEU) theory was formulated. This theory should be associated with the name of an Italian probabilist and actuary, de Finetti, who in 1937 explicated the essence of subjective probability, i.e. probability determined by the deciding agent itself and not necessarily through reference to rigorous probability theory, but through past events and personal experience. This theory, however, was formulated axiomatically in 1954, by Savage, an American mathematician and statistician. He wrote the utility function $(\mathrm{V}(\mathrm{F}))$ in the following manner:

$$
V(f)=\sum_{1=1}^{n} \mu\left(E_{i}\right) u\left(f\left(E_{i}\right)\right)
$$

where:

$\mu\left(E_{i}\right) \quad$ - subjective probability assigned to event $E_{i} ; \mu\left(E_{i}\right) \geq 0 \forall$, and $\sum_{i=1}^{n} \mu\left(E_{i}\right)=1$,

$u\left(f\left(E_{i}\right)\right)$ - utility of outcome $f\left(E_{i}\right)$ (Dhami, 2016).

SEU is sometimes referred to as the Bayesian approach to uncertainty. This results from the fact that as the agent receives new information, it processes it to transform the a priori judgements on subjective probability to a posteriori values. Although later scholars tried to modify the original SEU, e.g. by introducing weighting of probabilities (Handa in 1977) or through non-linear transformation of probabilities and lottery outcomes (Starmer in 2000), such attempts did not enjoy much interest among theoreticians and practitioners of risk management (Wilkinson and Klaes, 2012). The classical SEU, however, is widely applied to risk management in agriculture (Hoag (ed.), 2010; Hardaker et al., 2015).

An interesting attempt at integrating the EU and the SEU was made in 2002 by Rabin. It is known as the Standard Economic Model, or briefly: standard model. We shall explain its essence using the work by Wilkinson and Klaes. The model assumes that individual $i$ at time $t=0$ maximises the expected utility of outcome $x_{i}^{t}$ under probability distribution $p(s)$ of states on nature $s \in \mathrm{S}$. Hence, formally we have:

$$
\begin{aligned}
& \max _{x_{i}^{t} \in X_{i} \quad \sum^{\infty} \delta^{\prime}} \quad \sum p\left(s_{t}\right) U\left(x_{i}^{t} \mid s_{t}\right) \\
& =0 \quad s_{t} \in S_{t}
\end{aligned}
$$


We can see that the future utility is discounted using factor $\delta$, which expresses temporal preference of the individual. The latter strives for maximisation of utility (perfect rationality), while being egoistic, i.e. not taking into consideration utilities of other agents, uses conditional probabilities, i.e. following the Bayesian convention. Furthermore, the model assumes that all the income and assets are fully interchangeable. As it can be seen, we deal with very rigorous and idealistic assumptions. What indubitably deserves attention is the fact that the standard model combines microeconomic theory with theory of decision under risk and uncertainty.

\section{Approach to risk in EUT}

Virtually all the texts on the expected utility theory focus primarily on the risk aversion of decision-makers. This tendency is even clearer in the case of non-life insurance (Borch, 1992; Finsinger, 1983; Hax, 1964; Zweifel and Eisen, 2012). It is obvious because persons afraid of risk are the most interested in purchasing insurance policies. This issue is beyond dispute, and therefore deserves a broader discussion. This will be done based mainly on the work by Zweifel and Eisen.

The most general correlations between the expected utility function and risk aversion have been shown in Figure 1. The abscissa axis shows the changing wealth of the decision-makers, where $W_{1}$ is its lowest level, and $W_{2}$ - the maximum level. The corresponding utility has been shown on the ordinate axis as $v\left[W_{1}\right]$ and $v\left[W_{2}\right]$. The $E W$ symbol stands for the expected value of wealth, which has been determined based on the assumption that the probability $\pi$ of states $W_{1}$ and $W_{2}$ is identical and equal to 0.5 , so their weights in the utility function are identical. Utility $E W$ has been denoted on the vertical axis as $v[E W]=v\left[W_{0}\right]$. What is crucial for the insurance market and risk management, however, is $W_{s}$. It is the so-called certainty equivalent (CE). This is a general concept that allows to express lottery outcomes using non-random values. To be more specific: $\mathrm{CE}$ causes that a person aiming at maximising the expected utility function to be indifferent in the choice between the lottery gain $E W$ and a sure amount. In other words, such a person is willing to sacrifice a portion of the expected gain by buying e.g. an insurance policy in order to avoid risk, which then becomes a cost. However, if such a person was to participate in a game of chance, they would have to receive a risk premium (RP), which would compensate for the expected value of the game of chance. In Figure 1, this fact was depicted by marking on the abscissa axis the expected utility equivalent of sure gain and wealth $W_{0}$, i.e. as coordinate $E U\left(W_{0}\right)$. 


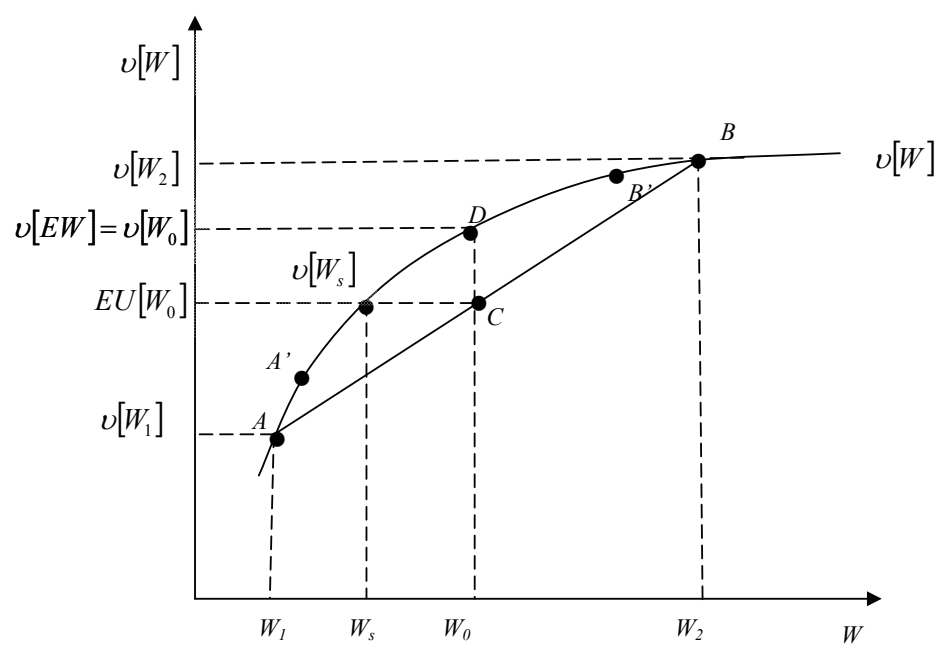

Fig. 1. Strictly concave utility function and risk aversion.

Source: own elaboration based on: Zweifel and Eisen (2012).

It follows from the above that the described case is the dominant case in the economic theory and the decision theory, i.e. the existence of the concave utility function of wealth, which in the light of Jensen's inequality implies that CE is less than EV. It can be seen in Figure 1, where wealth $W_{\mathrm{s}}$ (equivalent of CE) is less than $W_{0}$. Hence, we have:

$$
C E=E V-R P .
$$

It is worth adding that $\mathrm{CE}$ is very widely used in advanced reflection on risk management, which is best shown in the book by Robison and Barry (1987). This concept appears when modelling wealth, share equity, own capital, income, and costs. It follows from the simple fact that $\mathrm{CE}$ can be expressed in monetary units, which is impossible in the case of utility. There is also a need to add that the maximisation of the certainty equivalent is equivalent to the maximisation of expected utility and vice versa.

In Figure 1, the difference between wealth $W_{\mathrm{s}}$ and $W_{0}$ is referred to by Zweifel and Eisen as the willingness to pay for certainty (WTP) by a person characterised by risk aversion. This reduction in own wealth for the benefit of the insurer is supposed to be sufficient to allow the latter to finance the future compensation, cover its operating cost, including the cost of risk. If gain and loss, however, were certain, i.e. $\pi=1$, WTP would not be justified. In such a situation, points A and B in the Figure, utilities of a sure alternative $(\mathrm{w}[W 1])$ and expected utilities of wealth $W_{1}$ and $W_{2}$ would be equal. In such a context, insurance should be treated as a sure loss $(\pi=1)$, which has already occurred. In this sense, the preceding purchase of an insurance policy becomes the temporal subsidisation of the insurance firm, in the acceptance of the fact that the future loss is not certain $(\pi<1)$. In other words, 
the purchase of an insurance policy is reduction in wealth for a person characterised by risk aversion. This circumstance to a large extent explains the globally common unwillingness of the farmers to pay for insurance protection against many risks if the premiums are not extensively subsidised.

The more in-depth correlation between the risk premium, $\mathrm{CE}$ and the willingness to purchase insurance protection is shown in Figure 2. Here, $W_{0}$ represents the decision-maker's initial wealth. In addition, the random variable $\tilde{x}$ was introduced, whose aim is to represent the divergence of wealth from the expected value, while the expected value of the above variable is denoted as $E \widetilde{x}$. In insurance business, the latter is usually a negative value. $E \tilde{x}$ is simply the expected loss of wealth. The insurance premium calculated at that level is known as the actuarially fair premium. After certain transformations, the risk premium $(\rho)$ is defined by the following formula:

$$
\rho=E W-v^{-1}[E U[E W+\widetilde{X}]]
$$

As we can see, it is the difference between the expected value of the wealth and the inverse function of the expected utility of wealth exposed to risk. In Figure 2, it corresponds to the maximum WTP, which a person characterised by risk aversion could possibly pay to an insurance firm to become indifferent in a choice between the sure value of the wealth and the value exposed to risk. Then, the maximum WTP exceeds the fair premium.

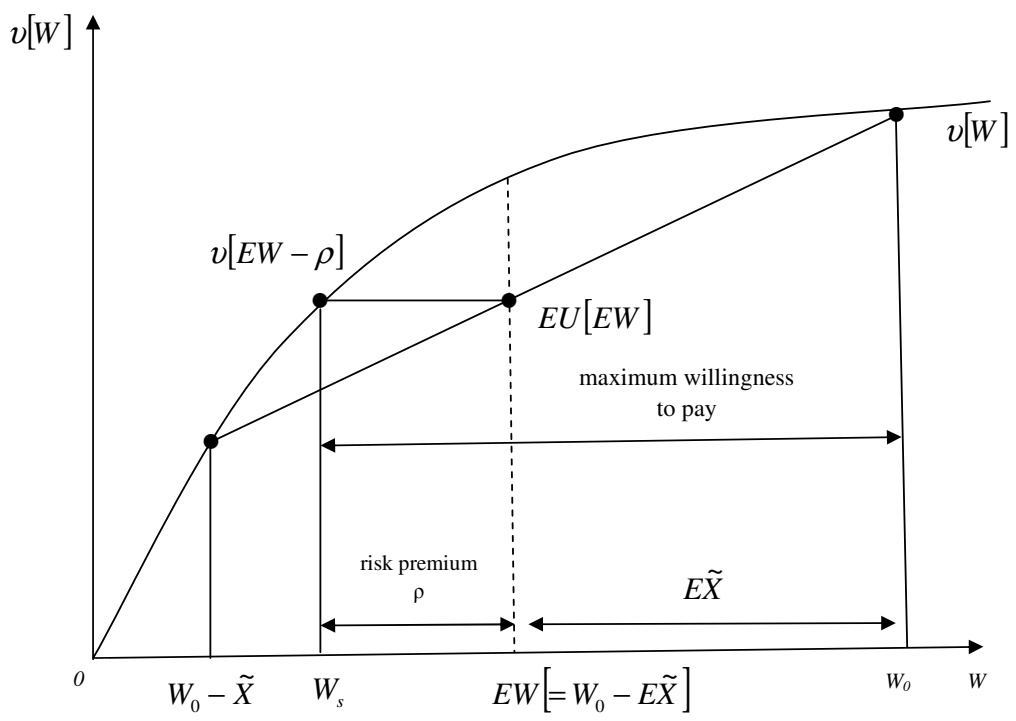

Fig. 2. Correlations between the certainty equivalent, risk premium and the willingness to pay for insurance.

Source: as for Fig. 1. 
The risk premium depends on the curvature of the utility function of the wealth, and thus on the intensity of risk aversion. As the curvature grows, the risk aversion increases, which is in turn followed by the risk premium itself. It is the subjective component. The second determinant of the risk premium is the shape of the probability density function for a risky lottery, which in insurance represents the distribution of losses of wealth. It is the objective component. It in turn results from the terminal wealth and probability of loss. It is generally assumed that more dispersed distributions and higher probabilities imply higher risk premiums. Finally, the last follows from the initial wealth, if there previously were no additional assumptions as to its relations with the curvature of the utility function.

The canonical approach to risk aversion is a proposition developed independently by Pratt (1964) and Arrow (1965). In the Arrow-Pratt convention, there are the following types of risk aversion:

1. absolute (RA),

2. relative (RR),

3. partial (RP).

The first one is the quotient of the second and the first derivative of the utility of the initial wealth:

$$
R_{A}:=-\frac{v^{\prime \prime}\left[W_{0}\right]}{v^{\prime}\left[W_{0}\right]}
$$

In turn, the risk premium, as the measure of the maximum willingness to pay for certainty will be:

$$
\rho=\frac{1}{2} \sigma_{x}^{2} \cdot R_{A}
$$

where: $\sigma_{x}^{2}$ represents the variance of wealth. In general, this measure has a sensible interpretation where the risk level does not depend on the level of wealth.

The relative risk aversion is given by the following formula:

$$
R_{R}:=-\frac{v^{\prime \prime}\left[W_{0}\right]}{v^{\prime}\left[W_{0}\right]} \cdot W=R_{A} \cdot W
$$

Then, the risk premium takes the following form:

$$
\rho^{*}=\frac{1}{2} \sigma_{x}^{2} \cdot R_{R}
$$

This aversion is simply a type of the flexibility of the utility function in relation to the changes in wealth, so it also reflects the impact of the curvature of the utility function on the risk premium. 
Partial risk aversion provides information on the changes in the willingness to pay for certainty under fluctuations of the quotient $\tilde{x}$ and the initial wealth $\left(W_{0}\right)$, denoted as $\beta$. Therefore, we have:

$$
R_{P}:=-W \cdot \frac{v^{\prime \prime}\left[W_{0}(1+\beta)\right]}{v^{\prime}\left[W_{0}(1+\beta)\right]}
$$

The following relations occur between the above risk aversion indices:

$$
R_{P}=R_{R}-\tilde{X} \cdot R_{A}
$$

It follows from the insurance theory itself that the demand for insurance products is a growing function of risk aversion. In practice, however, risk aversion shows significant differences if persons' wealth, age and sex are taken into consideration. Hence, the micro- and macroeconomic research to date proves that we can encounter the following types of risk aversion if we restrict ourselves to the wealth factor:

- constant absolute risk aversion (CARA),

- diminishing absolute risk aversion (DARA),

- diminishing relative risk aversion (DRRA),

- increasing relative risk aversion (IRRA),

- constant relative risk aversion (CRRA). 2012).

The last type is present most often and equal to about 2 (Zweifel and Eisen,

Risk aversion, however, implies important adverse consequences. As recently confirmed by Howley, Dillon, Heanue and Merdith (2017), persons characterised by this attitude abandon potentially higher expected profit or income or rate of return in exchange for their lower variability (Howley et al., 2017). In a longer time perspective, however, this strategy, per saldo, results in lower profit and income and rate of return than in the case of indifferent persons or even persons preferring the risk. In consequence, the studied farmers, unwilling to take risk, declared lower satisfaction from operating a farm and their entire lives. Maybe this can partially be explained by their lower willingness to experiment and implement broadly understood innovation. The above studies fit it the trend referred to as the "economics of happiness". Similar conclusions, however, are also drawn in finance, when the determinants for the increase in the economic value and the so-called antifragility of any systems (Taleb, 2013, 2016).

In the case of indifference to risk, the certainty equivalent is equal to the expected value, so the risk premium is absent in this case. It is described by the linear VNM utility function. For a risk taker, however, the certainty equivalent is higher than the expected value of wealth. These relations are then studied using the strictly convex VNM function. The precise division of the participants in the demand side of a competitive insurance market into three customer groups by risk is fundamen- 
tal for the efficient placement of commercial products on the market because it is the only instance where insurance firms can handle negative selection and moral hazard, and thus the consequences of asymmetric information. The segmentation of the demand side of the insurance market by risk is also crucial because the companies with an indifferent attitude, which, according to literature, are supposed to dominate, function differently from the risk averse or risk preferring person (Pearcy and Smith, 2015; Rotschild and Stiglitz, 1976; Spinnewijn, 2017).

\section{EU and agricultural insurance}

The above problem will be presented based on the reflection of Godwin and Smith (1995). These two American economists started with an agent who is faced with s possible outcomes and aims at maximising its expected utility given by the following formula:

$$
\sum_{s=1}^{S} \pi_{s} u\left(x_{s}\right)
$$

where:

$\pi_{s}$ - probability of the sth outcome,

$x_{s}-$ expected value of the sth outcome,

$u(\cdot)$ - general formula of the utility function.

As it can be observed, the agent strives for the maximisation of the weighted expected utility, where the weights are probabilities $\pi \mathrm{s}$. There is also a need to explain that according to the dominant convention, it has been assumed that the agent is characterised by risk aversion, so its utility function is concave. This means that it can be more willing to purchase insurance protection than a risk taker or a person indifferent to risk. For a risk adverse agent to purchase an insurance policy, it must be a worthwhile decision, and the insurance premium must be determined in an actuarially fair manner. The latter condition will be satisfied if the percentage insurance premium (percentage of the sums insured) will be equal to the probability that the insurer will have to pay the agent the agreed compensation (Czarny, 2006). Another approach to the actuarially fair premium, also referred to as the "fair value" or, in the insurance jargon, the "pure premium" or "risk only premium", is the one that assumes that it will be equal to the expected compensation (Zweifel and Eisen, 2012).

When the agent, e.g. a farmer, thinking about the possibility of purchasing an insurance policy, is confronted with two uncertain situations:

- $w_{1}=W$, i.e. absence of a loss,

- $w_{2}=W-L$, i.e. occurrence of a loss.

Where W represents the agent's wealth, $L$ - the loss, and $\pi$ - the exoneously defined probability of the latter. The insurance contract, on the other hand, includes premium $\alpha$ and provides for the payment of amount $L$ when the agreed insured event occurs. Assuming that the insurer is neutral towards risk, and this assumption is nearly universally accepted, its profit will be equal to zero, which implies that 
this is the case of a competitive market. The premium is then actuarially fair, which is expressed by the following formula:

$$
\alpha=\pi L
$$

If, instead of the monetary amount of the premium $(\alpha)$, we express it as a percentage, $q$ (or in a dimensionless manner or as a physical unit of the insured object), i.e. a percentage insurance premium, and $z$ will stand for the quantity of purchased insurance protection (e.g. ha or a head of livestock or in the form of a defined monetary sums insured), the condition of the insurer's zero profit is written as:

$$
q=\pi
$$

hence, this is the first method of how to express the actuarially fair premium.

The agent's decision problem now boils down to the selection of parameter $z$, which is supposed to maximise its utility:

$$
\max \left[(1-\pi) U\left(w_{1}\right)+\pi U\left(w_{2}\right)\right]
$$

under the following restrictions:

$$
\begin{gathered}
w_{1}=W-q z \\
w_{2}=W-L+z-q z
\end{gathered}
$$

The primary existence for the existence of a maximum is written as:

$$
(1-\pi) q U^{\prime}(W-q z)=\pi(1-q) U^{\prime}(W-L+z-q z)
$$

If the premium is actuarially fair, we have:

$$
U^{\prime}(W-q z)=U^{\prime}(W-L+z-q z)
$$

where $U$ 'stands for the first derivative.

It follows from the above that the optimum quantity of purchased insurance protection $(z)$ should be equal to the expected loss $(L)$. In other words, insurance (coverage) should be full, so there should be neither underinsurance nor excessive and overinsurance. In practice, the actuarially unfair premiums dominate, and insurers want to achieve some profit.

The above reflection can be summarised graphically (Figure 3 ). Here, the point of entry is the agent's zero wealth, where wealth $\mathrm{W}$ in state $\mathrm{w} 1$ is equal to wealth $W-L$ in state $w_{2}$. A risk averse agent, however, can seek insurance protection with slope, moving along the fair game line, i.e. line of a game where the player's profit 
is on average zero (expected value EV equals zero) or the player has to play for participation an amount equal to the expected value of the game. In other words, it is a game where the expected values of individual players are identical. As it can be seen, the optimum point is A. In insurance literature, the fair game line is also referred to as fair insurance line or transformation line, which transfers wealth from state $w_{1}$ to $w_{2}$. In Figure 3, there is also the $45^{\circ}$ line. This is the so-called certainty line, where state $\mathrm{w} 1$ is identical to w2. It simply represents indifference to risk.

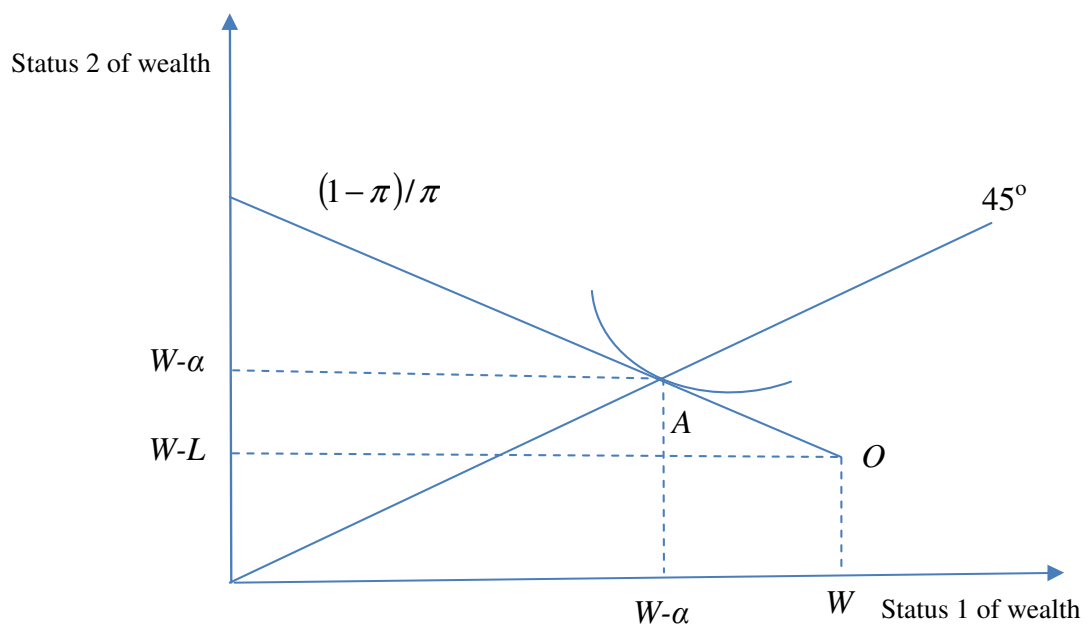

The remaining symbols are explained in the text.

Fig. 3. Optimum purchased quantity of insurance protection on a competitive market.

Source: Goodwin and Smith (1995).

\section{Conclusion}

The von Neumann-Morgenstern axiomatic utility theory is a very rigorous construction, where all the assumed conditions should be satisfied at the same time. This is both its advantage and disadvantage. All in all, it can serve as a point of entry and reference for an analysis, modelling and simulation of decision making problems under risk and uncertainty, including problems related to business insurance in agriculture and possible public intervention in this area. It is due to this theory that we are able to understand the difference between the situation of certainty and risk, and in turn, we can combine into a cohesive system the expected value of a lottery, risk premium, risk aversion, certainty equivalent, and the maximum willingness to pay for certainty, i.e. the actuarially fair amount of the insurance premium. On the other hand, the VNM hypothesis is not a sufficient model for the analysis of numerous aspects of risk occurrences, their effects in the actual business activity, and the complex nature of insurance contracts. For instance, it pays insufficient attention to the reasons for indifference and preference of risk. In some 
cases, it simply fails (paradoxes: Allais paradox of 1953, Ellsberg paradox of 1961 and Rabin paradox of 2000) and the so-called anomalies, it totally omits the effects of asymmetric information (negative selection and moral hazard), does not deal with types and moments of random variable distributions, including random losses. Therefore, this hypothesis should in general be continuously verified empirically, particularly with consideration of the achievements of behavioural economics and finance, and prospect theory by Kahneman and Tversky, which is based on it. The non-expected utility concepts will be the topic of a separate article by the author. 


\section{References}

Ackert, F.L., Deaves, R. (2012). Understanding Behavioral Finance. India: Cengage.

Borch, H.K. (1992). Economics of Insurance. North-Holland, Amsterdam, London, New York, Tokyo.

Czarny, E. (2006). Mikroekonomia. Warszawa: Polskie Wydawnictwo Ekonomiczne.

Dhami, S. (2016). The foundations of behavioral economic analysis. Oxford: Oxford University Press.

Döring, T. (2015). Öffentliche Finanzen und Verhaltensökonomik. Zur Psychologie budgetwirksamen Staatstätigkeit. Wiesbaden: Springer Gabler.

Finsinger, J. (1983). Versicherungsmärkte. Frankfurt, New York: Campus Verlag.

Goodwin, K.B., Smith, H.V. (1995). The Econnomic of Crop Insurance and Disaster Relief. Washington: AEI Press.

Goodwin, K.B., Smith, H.V. (2014). Theme Overview: The 2014 Farm Bill - An Economic

Welfare Disaster or Triumph?. Choices, vol. 29, no. 3.

Hardaker, B.J., Gudbrand, L., Anderson, R.J., Huirne, M.B.R. (2015). Coping with Risk in Agriculture. $3^{\text {rd }}$ Edition. Applied Decision Analysis. Wallingford, Boston: CABI.

Hax, K. (1964). Grundlagen des Versicherungswesen. Wiesbaden: Verlag Gabler.

Hoag, D.L. (ed.) (2010). Applied Risk Management in Agriculture. Boca Raton, London, New York: CRC Press.

Howley, P., Dillon, E., Heanue, K., Merdith, D. (2017). Worth the Risk? The Behavioral Path to Well-Being. Journal of Agriultural Economics, vol. 68, no. 2.

Jehle, A.G., Reny, J.P. (2011). Advanced Microeconomic Theory. $3^{\text {rd }}$ Edition, London, New York: Pearson.

Kunreuther, C.H., Pauly, V.M., McMorrow, S. (2013). Insurance \& Behavioral Economics. Improving Decisions in the Most Misunderstood Industry. New York: Cambridge University Press.

Miranda, J.M., Farrin, K. (2012). Index Insurance for Developing Countries. Applied Economic Perspective and Policy, vol. 34, no. 3.

Moss, B.C. (2010). Risk, Uncertainty and the Agricultural Firm. New Jersey, London: World Scientific.

OECD (2017a). Evaluating Dynamics, Sources and Drivers of Productivity Growth at the Farm Level. Paris.

OECD (2017b). Evaluating of the EU Common Agricultural Policy (CAP). Paris.

Pearcy, J., Smith, V. (2015). The Tangled Web of Agricultural Insurance: Evaluating the Impacts of Government Policy. Journal of Agricultural and Resource Economics, vol. 40, no. 1.

Rejda, E.G., McNamara, J.M. (2017). Principles of Risk Management and Insurance. Thirteenth Edition. London, New York: Pearson.

Robison, L., Barry, P. (1987). The Competitive firm's response to risk. New York: Macmillan.

Rotschild, M., Stiglitz, J.E. (1976). Equilibrium in competitive insurance markets: an essay on the economics of the theory. Quarterly Journal of Economics, vol. 90, no. 4.

Spinnewijn, J. (2017). Heterogenity, Demand for Insurance, and Adverse Selection. American Economic Journal: Economic Policy, vol. 9, no. 1.

Taleb, N.N. (2013). Antykruchość. O rzeczach, którym stuża wstrząsy. Warszawa: Kurhaus.

Taleb, N.N. (2016). Zwiedzeni przez losowość. Tajemnicza rola przypadku w życiu i w rynkowej grze. Warszawa: Kurhaus.

Wilkinson, N., Klaes, M. (2012). An Introduction to Behavioral Economics. ${ }^{\text {nd }}$ Edition. New York: Palgrave Macmillen.

Zweifel, P., Eisen, R. (2012). Insurance Economics. Berlin, Heidelberg: Springer-Verlag. 


\title{
NEOKLASYCZNE PODEJŚCIE DO TRADYCYJNYCH UBEZPIECZEŃ GOSPODARCZYCH - WSTĘP DO TEORII UBEZPIECZEŃ ROLNYCH
}

\begin{abstract}
Abstrakt
Rolnictwo współczesne należy do najbardziej ryzykownych działalności gospodarczych. Obok znanego wcześniej ryzyka produkcyjnego, cenowego i rynkowego, a później także finansowego, obecnie producenci rolni coraz częściej konfrontowani sa z ryzykiem instytucjonalnym i ze sfery zarzadzania personelem oraz zwiąanym ze zmiana klimatu. Równocześnie rolnicy dysponuja wieloma narzędziami i strategiami przeciwdziałania zagrożeniom i łagodzenia ich negatywnych skutków. Wśród tych instrumentów i strategii zarządzania ryzykiem wciąż duże znaczenie odgrywaja tradycyjne/konwencjonalne ubezpieczenia upraw, zwierząt i rzeczowych składników majątku. W tym kontekście podstawowym celem artykutu jest uogólnienie podstaw teoretycznych powyższych ubezpieczeń, ale ograniczone do historycznie najstarszego ich ujęcia, a więc na gruncie mikroekonomii neoklasycznej i klasycznej teorii decyzji. Zgodnie z istniejąca tu konwencja najpierw analizuje się istotę teorii/hipotezy użyteczności oczekiwanej von Neumanna-Morgesterna. Następnie przybliża się treść awersji do ryzyka. W ostatniej części artykułu konkretyzuje się natomiast założenia teorii użyteczności oczekiwanej na przykładzie ubezpieczeń rolnych.
\end{abstract}

Słowa kluczowe: awersja do ryzyka, ubezpieczenia rolne, użyteczność oczekiwana.

Accepted for print: 18.04.2018.

Unless stated otherwise all the materials on the website are available under the Creative Commons Attribution 4.0 International license.

Some rights reserved to the Institute of Agricultural and Food Economics - National Research Institute.

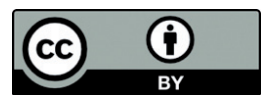

